\title{
ANTI-INFLAMMATORY ACTIVITY OF BACTERIA ASSOCIATED WITH MARINE SPONGE (HALICLONA AMBOINENSIS) VIA REDUCTING NO PRODUCTION AND INHIBITING CYCLOOXYGENASE-1, CYCLOOXYGENASE-2, AND SECRETORY PHOSPHOLIPASE A2 ACTIVITIES
}

\author{
YOSIE ANDRIANI ${ }^{1 *}$, LENI MARLINA ${ }^{1}$, HABSAH MOHAMAD ${ }^{1}$, HERMANSYAH AMIR ${ }^{2}$, SITI AISHA M RADZI ${ }^{1}$, \\ JASNIZAT SAIDIN ${ }^{1,3}$
}

${ }^{1}$ Institute of Marine Biotechnology, University of Malaysia Terengganu, Kuala Nerus, Terengganu, Malaysia. ${ }^{2}$ Educational Chemistry Program, Faculty of Teacher Training and Education, Bengkulu University, Bengkulu, Indonesia. ${ }^{3}$ School of Marine Sciences and Environmental, Universiti Malaysia Terengganu, Kuala Nerus, Malaysia. Email: yosieandriani@gmail.com

Received: 20 May 2017, Revised and Accepted: 13 July 2017

ABSTRACT

Objective: This study aimed to investigate the anti-inflammatory activity of methanol extract and fractions of bacteria associated with sponge (Haliclona amboinensis) and to evaluate their effect in reducing NO production and inhibiting cyclooxygenase-1 (COX-1), cyclooxgenase-2 (COX-2) and secretory phospholipase A2 (sPLA2) activity.

Methods: All bacterial isolates were cultured and supernatants were collected for the extraction of secondary metabolites using diaion HP-20 to obtain methanol extracts. Evaluation of cytotoxicity property was carried out on macrophage cell lines (RAW264.7) by 3-(4,5-dimethylthiazol2-yl) 2,5-diphenyl tetrazoliumbromide assay. Anti-inflammatory screening was done by inducible nitric oxide assay on RAW264.7 cell lines with lipopolysaccharide (LPS) stimulation. Dianion HP-20 was used to remove salt content. A selected methanol extract was subjected to further fractionations by C- 18 reverse phase and their anti-inflammatory potential was evaluated by COX-1 and COX-2, and sPLA2 enzymatic assay.

Results: Seven methanol extracts showed no cytotoxic property against RAW 264.7 cell line (inhibitory concentration $50 \%>30 \mu \mathrm{g} / \mathrm{ml}$ ) and selected for anti-inflammatory screening assay. Result showed methanol extract HM 1.2 reduced NO production $>80 \%$ and it has been selected for phytochemical screening, further fractionations and assay. Phytochemical screening showed alkaloids and terpenoids present in the HM 1.2. The HM 1.2 and its fractions (F1, F2, F1C1, F1C2, F1C3, and F1C4) were proven to inhibit COX-1, COX-2, and sPLA2 activity in the range of 60.516-116.886\%, 20.554$116.457 \%$, and $70.2667-114.8148 \%$, respectively.

Conclusions: This study revealed that bacteria associated with H. amboinensis have produced anti-inflammatory activity via reducing NO production and inhibiting COX-1, COX-2, and sPLA2 activity.

Keywords: Haliclona amboinensis, Associated bacteria, Anti-inflammatory, Inducible nitric oxide, Cyclooxygenase-1, Cyclooxygenase-2, Secretory phospholipase A.

(C) 2017 The Authors. Published by Innovare Academic Sciences Pvt Ltd. This is an open access article under the CC BY license (http://creativecommons. org/licenses/by/4. 0/) DOI: http://dx.doi.org/10.22159/ajpcr.2017.v10i11.20094

\section{INTRODUCTION}

Activation of macrophage plays an important role in the initiation and propagation of inflammatory responses by production of cytokines, interleukin $1 \beta$, tumor necrosis factor-alpha, NO, cyclooxygenase-2 (COX-2), and other inflammatory mediators. Over-expression of the inflammatory mediators in macrophage is involved in many inflammation related diseases, such as rheumatoid arthritis, atherosclerosis, chronic hepatitis, and pulmonary fibrosis [1]. A number of drugs have been designed to treat inflammation in the human body, and three major groups of these drugs commonly used in the treatment of inflammatory disease are corticosteroids, nonsteroidal anti-inflammatory drugs, and disease-modifying anti rheumatoid drugs, which include biological agents. These drugs are widely used and are effective in treating inflammatory diseases but give side effects to the body, such as gastrointestinal ulceration, bleeding, and platelet dysfunction. This study investigated a new source from nature, namely sponges, as a potential alternative medicine that can reduce inflammation. There are some active compounds from sponges that have proven beneficial to humans such as anti-bacteria, anticancer, antidiabetic and antioxidant, antifouling, and anti-inflammatory [2-7].

Due to these benefits, many researchers have been interested in studying and exploring the sponges. The large exploitation of sponges will interfere with their sustainability and their habitat. For example, to produce $1 \mathrm{~g}$ of anticancer compound, one or more ton of sponges are needed [8]. Therefore, sponge-associated bacteria can be used as an alternative source to replace the raw sponge specimens to help sponge population recovery. Although many specimens of sponges have been studied for their potentials to cure many diseases, anti-inflammatory potential of sponge-associated bacteria, especially (Haliclona amboinensis) - associated bacteria on RAW254.7 cells has not been studied yet and its mechanism of action as anti-inflammatory agent has never been investigated. Moreover, H. amboinensis sponge was chosen since this genus sponge was abundant at the selected sampling area and it was reported to possess many bioactivities. Thus, this study aimed to investigate the anti-inflammatory activity of methanol extracts and fractions of bacteria associated with marine sponge (H. amboinensis) and to evaluate their effect in reducing NO production and inhibiting COX-1, COX-2, and secretory phospholipase A2 (sPLA2) enzymes activity.

\section{MATERIALS AND METHODS}

Materials

2,2-diphenyl-1-picrylhydrazyl, quercetin, and NG-monomethyl-Larginine were purchased from Sigma-Aldrich (MO, USA). Kit-560131 
for COX-1 and COX-2, and kit-10004883 for sPLA2 were purchased from Cayman Chemical (MI, USA). All of other reagents and organic solvents were analytical grades from Sigma-Aldrich.

\section{Sampling process and bacteria isolation}

The sample of H. amboinensis was collected on April 2014 in Bidong Island, Terengganu, Malaysia. After the collection, the sponge was cut into small pieces (about $2 \mathrm{~mm}^{2}$ ) using sterile technique, and the pieces were transferred into a sterile Eppendorf tube and washed three times using sterile seawater $(1000 \mu \mathrm{L})$ with gentle shaking (approximately for 1 minute). At the end of the washing processes, sponge pieces were crushed using a sterile pipette tip and $200 \mu \mathrm{L}$ were seeded onto marine nutrient agar (MNA). Plates were incubated at $20^{\circ} \mathrm{C}$ and observed daily for 2 weeks. Bacteria colonies were picked up daily, marked and streaked onto fresh appropriate media. Bacteria were selected based on color, colony morphology and consistency, growth time, and pigment secreted in the media. The pure colonies were then stocked into $50 \%$ of glycerol and marine broth and kept in $-80^{\circ} \mathrm{C}$ before further experiments.

\section{Preparation of methanol extract from $H$. amboinensis-associated bacteria}

Each isolated bacteria was cultured in marine nutrient broth (MNB) for $24 \mathrm{hrs}$, and then supernatants were separated from bacteria cells via centrifugation (6000 rpm, 15 minutes). Furthermore, Dianion HP-20 was used to remove salt content and yielded methanol extract. Before being used, the dianion beads were activated first by soaking them in methanol for 15 minutes. Then, they were placed into glass column chromatography, and methanol solvent was removed. Methanol was replaced with deionized water and left aside for 10 minutes. The supernatant free of bacteria was added into column chromatography and run through at a flow rate of $5 \mathrm{ml} /$ minutes. Then, deionized water was passed through the column to remove excessive salt in retained crude extract. Methanol was used to elude the retained crude extract. The solvents were removed by rotary evaporator. Fractionation of selected methanol extract was done by C-18 reverse phase by column chromatography using water:acetonitril $(6: 4)$ as a solvent system, followed by gradient elution of sequential water and acetonitril.

\section{Phytochemical screening}

Phytochemical analysis of the chemical constituents of the methanol extract was adapted from Yadav and Agarwala [9].

Screening of cytotoxicity property of methanol extracts from sponge-associated bacteria on RAW264.7 cell line viability The RAW cell line was obtained from the American Type Culture Collection. The RAW cell lines were kept in DMEM media (Sigma) with $10 \%$ fetal bovine serum (ICN Biomedicals, Inc., Aurora, $\mathrm{OH}$ ) and $1 \%$ penicillin-streptomycin at $37^{\circ} \mathrm{C}$ under $5 \% \mathrm{CO}_{2}$. The suspension cells were dispensed $(100 \mu \mathrm{l})$ in triplicates into 96 -well plates at optimized concentrations of 20000 cells/well in complete medium of DMEM (Sigma) as described previously [10]. The sample was prepared in varying concentration by serial dilution in DMEM medium with concentration of $100,50,25,12.5,6.25,3.125,1.56$, and $0.78 \mu \mathrm{g} / \mathrm{ml}$ in 96 well plates. Then, the plates were incubated for $72 \mathrm{hrs}$ at $37^{\circ} \mathrm{C}, 5 \%$ $\mathrm{CO}_{2}, 90 \%$ humidity.

\section{3-(4,5-Dimethylthiazol-2-yl) 2,5-diphenyl tetrazoliumbromide (MTT) assay}

The assay of each concentration was performed in triplicates, and untreated well cell population was performed as control wells. After $72 \mathrm{hrs}$, colorimetric MTT method assay was used to measure the living cells (slightly modified from Andriani et al. [11]). The MTT was dissolved at $5 \mathrm{mg} / \mathrm{ml}$ in phosphate-buffered saline. $20 \mu \mathrm{l}$ of MTT solution was added into each well, and the plates were further incubated at $37^{\circ} \mathrm{C}$ in the incubator for $4 \mathrm{hrs}$. Supernatants were then discarded and $100 \mu \mathrm{l}$ of dimethyl sulfoxide (DMSO) was added to the cultures and mixed thoroughly to dissolve the dark blue crystals formazan. The formazan quantification was then read by spectrophotometer at $571 \mathrm{~nm}$. The optical density (OD) of the samples was compared with that of the control to obtain the percentage viability, as stated below:

Cells viability $(\%)=\left(\left(\mathrm{OD}_{571}(\right.\right.$ sample $) / \mathrm{OD}_{571}($ control $\left.\left.)\right) \times 100 \%\right)[12]$

Anti-inflammatory screening by inducible nitric oxide (iNOS) assay on RAW 264.7 cell line with lipopolysaccharide (LPS) stimulation

\section{Standard nitrite assay}

The stock solution of sodium nitrite was prepared using DMEM. A series of sodium nitrite concentrations were used to estimate the concentration of nitrites produced, starting from a concentration of $0-80 \mu \mathrm{M} .100 \mathrm{ml}$ of each standard solution was prepared on 96 well plates. Furthermore, $100 \mu \mathrm{l}$ of Griess reagent was added into each well and mixed. After incubation for 30 minutes at room temperature, the absorbance was read at $540 \mathrm{~nm}$ in micro plate reader [13].

Measurement of NO production on RAW264.7 cell line with LPS stimulation after treated by selected sample from bacteria associated with $H$. amboinensis

The RAW264.7 cells were plated at $2 \times 10^{5}$ cells/well in 96 well plates and then incubated $24 \mathrm{hrs}$, and then cells were stimulated with LPS $(1 \mu \mathrm{g} / \mathrm{ml})$ and treated with sample to each well with the different concentration (two fold dilution from $100 \mu \mathrm{g} / \mathrm{ml}$ ) then incubated for $24 \mathrm{hrs}$. Nitrite levels in cultured media were determined using Griess Reagent assay and presumed reflect NO levels. Briefly, $100 \mu \mathrm{l}$ of cell culture media was mixed with $100 \mu \mathrm{l}$ of Griess reagent (equal volumes of $1 \%(\mathrm{w} / \mathrm{v})$ sulfanilamide in $5 \%(\mathrm{v} / \mathrm{v})$ phosphoric acid and $0.1 \%(\mathrm{w} / \mathrm{v})$ naphthyl ethylenediamine dihydrochloride), incubated at room temperature for 10 minute and then the absorbance was measured at $540 \mathrm{~nm}$. The nitrite concentrations were calculated using sodium nitrite standard curve. The methodology was slightly modified from Lau et al [14].

Effect of methanol extract and fractions from bacteria associated with $H$. amboinensis on COX-1, COX-2, and SPLA2 activities [15]

\section{COX-1 and COX-2 enzymatic assay}

The stock solution was prepared with $10 \mathrm{mg} / \mathrm{ml}$ of selected methanol extract dissolved in 100\% DMSO. The extract was tested in duplicates of $5 \mu \mathrm{g} / \mathrm{ml}$ using a commercial COX inhibitory screening assay kit (Cayman test kit - 560131, Cayman Chemical Company) following the manufacturer's protocol. The COX inhibitor screening assay directly measured the amount of prostaglandin (PG) $2 \alpha$ produced in the COX reaction. Arginine was run as the positive control for the inhibition of COX-1 and COX-2. A volume of $10 \mu \mathrm{l}$ each of sample and vehicle was diluted to $20 \mu \mathrm{l}$ with $0.1 \mathrm{M}$ Tris- $\mathrm{HCl} \mathrm{pH} 8.0$ and pre-incubated with the enzyme at $37^{\circ} \mathrm{C}$ for 15 minutes before the addition of arachidonic acid (AA). The reaction was initiated by the addition of $10 \mu \mathrm{l} 10 \mathrm{mM} \mathrm{AA}$ and the tube was incubated at $37^{\circ} \mathrm{C}$ for another 2 minutes. Reaction was terminated by the addition of $50 \mu \mathrm{l} 1 \mathrm{~N} \mathrm{HCl}$ and saturated stannous chloride. Assays were performed using 100 units of ovine COX-1 and human recombinant COX-2. An aliquot was removed and the prostanoid produced was quantified spectrophotometrically via enzyme immunoassay.

\section{sPLA2 enzymatic assay}

The selected methanol extract was tested in triplicates at $5 \mu \mathrm{g} / \mathrm{ml}$ using the sPLA2 (Type $\mathrm{V}$ ) inhibitor screening assay kit (Cayman test kit - 10004883, Cayman Chemical Company) following the manufacturer's protocol. This assay kit contained a human recombinant Type V sPLA2 and reaction mixtures. Arginine was used as the positive control. A total of $10 \mu \mathrm{l}$ each of test extract and vehicle were preincubated with $25 \mathrm{mM}$ Tris-HCl buffer $\mathrm{pH} 7.5$ containing $10 \mu \mathrm{l}$ enzymes in a 96-well plate. The reaction was initiated by addition of $200 \mu \mathrm{l} 1.66 \mathrm{mM}$ diheptanoylthio-PC, and the plate was shaken for 30 seconds and incubated at $25^{\circ} \mathrm{C}$ for 15 minutes. Further, $10 \mu \mathrm{l}$ 5,5'-dithio-bis-(2- nitrobenzoic acid) was added to stop the enzymatic reaction and to allow for color development. The plate was placed on a shaker for 1 minute to mix, and absorbance was measured at $405 \mathrm{~nm}$ using plate reader. 
Statistical analysis

All the experiments were conducted in triplicates, and the data were presented as mean values \pm standard deviation.

\section{RESULTS AND DISCUSSION}

\section{Isolation of bacteria}

A total of 19 bacteria from the sample H. amboinensis were isolated on MNA. These bacteria were observed and selected based on the color, colony morphology, and pigment secreted in the media. The results showed that almost all of the bacteria were stained as Gramnegative bacteria except one sample (HM 1.3) which was stained as Gram-positive bacteria (Table 1). The Gram staining has become a common diagnostic staining reaction in bacteriology. The gram type is an important criterion for describing bacteria and their taxonomy. Each of these bacteria was cultured in MNB, and the supernatantfree bacteria were extracted via Diaion HP-20, then evaporated. A total of 19 methanol extracts were yielded and used for further assay.

Screening of cytotoxicity property of methanol extracts from sponge-associated bacteria on macrophage cell lines (RAW264.7) viability

In this study, the cell viability of methanol extracts was determined according to the cytotoxicity property using MTT assay against RAW264.7 cell lines. The cytotoxicity property of methanol extracts of sponge-associated bacteria is shown in Fig. 1. The results showed the cytotoxicity property of 19 samples of methanol extracts according to their inhibition concentration value. There were seven out of nineteen samples considered nontoxic against RAW264.7 cell lines (inhibitory concentration $50 \%\left[\mathrm{IC}_{50}\right]>30 \mu \mathrm{g} / \mathrm{ml}$ ), namely, HM 1.2, HM 1.3, HM 1.4, HM 1.5, HM 1.10, HM 1.11, and HM 1.3 (2). Cytotoxicity property of the samples were interpreted according to the range of their inhibition value and interpreted as follows; IC value $<1.0 \mu \mathrm{g} / \mathrm{ml}$ is defined as highly toxic, value between 1.0 and $10.0 \mu \mathrm{g} / \mathrm{ml}$ is toxic, value between 10.0 and $30.0 \mu \mathrm{g} / \mathrm{ml}$ is moderately toxic, and value $>30.0 \mu \mathrm{g} / \mathrm{ml}$ is defined as nontoxic (Adapted from Andriani et al. [16]). Therefore, sample extracts with $\mathrm{IC}_{50}$ value more than $30 \mu \mathrm{g} / \mathrm{ml}$ were considered nontoxic on RAW264.7 cell lines and were chosen for further anti-inflammatory assay. Cytotoxicity activities of all samples were analyzed first to confirm that our samples were not cytotoxic against tested cell lines. This is important in the NO assay to indicate that the reduction of NO release is due to the anti-inflammatory activity, not derived from cell death caused by cytotoxic activity of the samples.

The macrophage cell line was chosen for cytotoxicity and antiinflammatory studies since the macrophages are generally important components in the immune defense mechanism. During the progress of inflammation, macrophages actively participate in inflammatory responses by releasing proinflammatory cytokines and mediators [17].

Table 1: Bacteria stain and morphology

\begin{tabular}{llll}
\hline $\begin{array}{l}\text { Number } \\
\text { of sample }\end{array}$ & Sample's code & Gram & $\begin{array}{l}\text { Morphology } \\
\text { of bacteria }\end{array}$ \\
\hline 18 & HG 1.4, HG 1.5, HG 1.6, & $\begin{array}{l}\text { Negative } \\
\text { Bacillus }\end{array}$ & $\begin{array}{l}\text { Negative } \\
\text { Bacillus }\end{array}$ \\
& HM 1.12, HM 1.1, & Negative & Bacillus \\
& HM 1.4, HM 1.5, & Negative & Bacillus \\
& HM 1.8, HM 1.9, & Negative & Bacillus \\
& HM 1.10, HM 1.11, & Negative & Bacillus \\
& HG 1.1, HG 1.2, HG 1.3, & Negative & Bacillus \\
& HG 1.7, HM 1.3 (2) & Negative & Bacillus \\
& HM 1.2, HM 1.6 & Positive & Bacillus \\
\hline
\end{tabular}

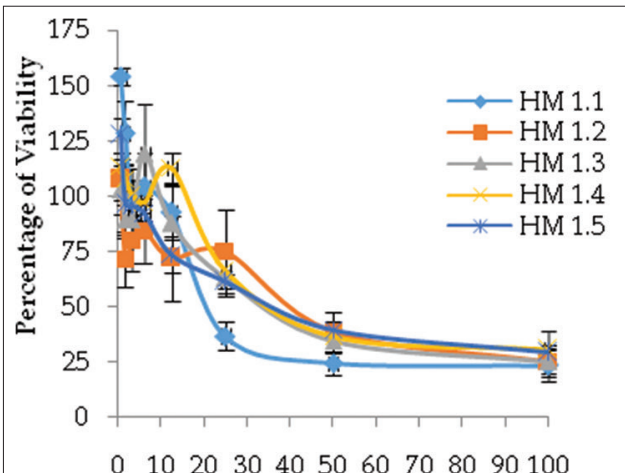

a

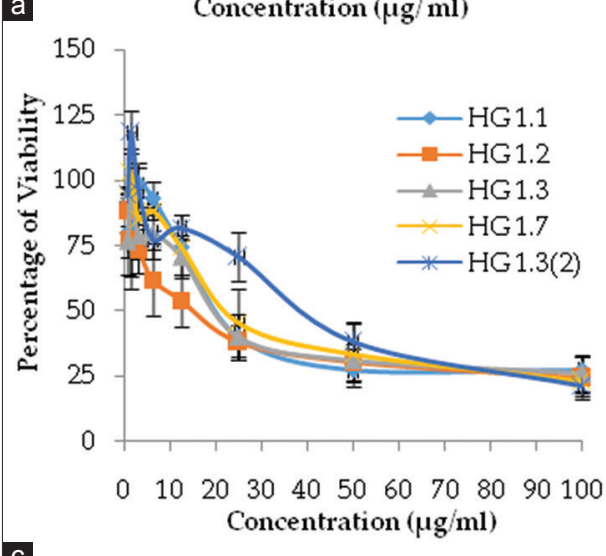

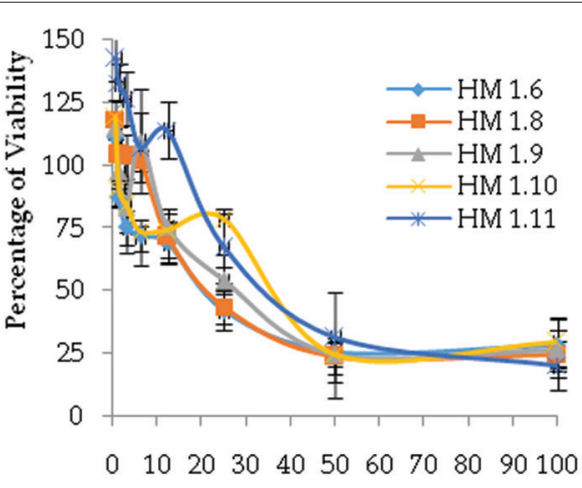

b

Concentration $(\mu \mathrm{g} / \mathrm{ml})$

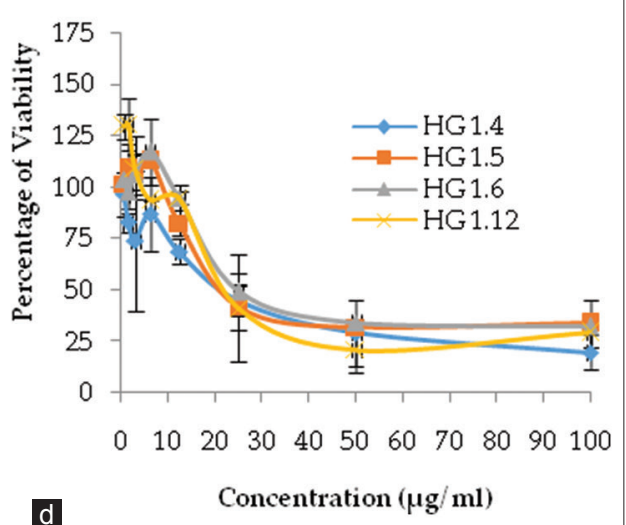

Fig. 1: Percentage of cell viability from methanol extracts of bacteria associated Haliclona amboinensis on RAW264.7 cell lines. (a) HM 1.1, HM 1.2, HM 1.3, HM 1.4 and HM 1.5, (b) HM 1.6, HM 1.8, HM 1.9, HM 1.10 and HM 1.11, (c) HG 1.1, HG 1.2, HG 1.3 and HG 1.7, (d) HG 1.4, HG 1.5, HG 1.6 and HG 1 
Anti-inflammatory activity of methanol extracts and fractions from bacteria associated with $\boldsymbol{H}$. amboinensis

Inhibition of NO production on macrophage cell lines (RAW264.7) with LPS stimulation

A standard curve of sodium nitrate with very strong coefficient correlation $\left(\mathrm{R}^{2}\right)$ of 0.9713 (Fig. 2) was used for quantification of NO produced by RAW 264.7 cells treated with different samples. Since the level of nitrite can be obtained from the standard curve, the level of nitrites produced in the sample treated wells can be calculated using the regression plot obtained [18]. Raw data from the anti-inflammatory assay represent the production of NO from the cell supernatant.

LPS is a nitrite synthase inducer, and when macrophages are activated with the LPS, there is an increase in the nitrite production by the independent NOS enzyme (iNOS). Yoon et al. [19] stated that LPS stimulation alone in murine macrophage RAW264.7 cells can induce iNOS transcription and protein synthesis and subsequent NO production. Inhibitory activity of NO production with LPS stimulated on RAW264.7 by extract HM 1.2 and its fractions from bacteria associated with $H$. amboinensis is shown in Fig. 3. There were five out of seven methanol extracts that showed potential as anti-inflammatory agents through inhibition of NO production (Fig. 3a). Three extracts showed high inhibition of NO production of more than 80\%, namely, HM 1.3, HM 1.2, and HM 1.4. The lowest inhibition was shown by HM 1.3 (62.353\%). All results were compared to the positive control $\mathrm{N}^{\mathrm{G}}$-monomethyl-LArginine, with the percentage of NO production at $62.305 \%$.

Active methanol extract HM 1.2 was chosen for further fractionation since it was extracted from the bacteria which grew easily compared to the other active methanol extracts (HM 1.3 and HM 1.4). The process yielded eight combined fractions, and all of these fractions were further used for screening anti-inflammatory activity by iNOS assay. The results in Fig. 3b revealed that all of the fractionations from extract HM 1.2 showed high inhibitory activity on NO production (more than $80 \%$ ). The highest percentage came from fraction $6(83.952 \%)$, and the lowest percentage was obtained by fraction $5(61.452 \%)$ at the concentration of $0.78 \mu \mathrm{g} / \mathrm{ml}$ for both fractions. The data showed that these fractions reduced NO production at a level higher than positive control (NGmonomethyl-L-arginine). Fraction 1 (fr1), fraction 2 (fr2), fraction 6 (fr6), fraction 7 (fr7), and fraction 8 (8) were the most active fraction compared to fraction 3 (fr 3 ), fraction 4 (fr4), and fraction 5 (fr5). They also showed higher activity than positive control (NG-monomethylL-arginine) with the percentage of the inhibition of more than $80 \%$. Further fractionation was done for fraction 1 since it had more weight than the other fractions.

Moreover, further fractionation of fr1 yielded four fractions, namely, F1C1, F1C2, F1C3, and F1C4 (Fig. 3c). All fractions possessed anti-inflammatory activity on RAW264.7 cell lines. In the lowest concentration $(30 \mu \mathrm{g} / \mathrm{ml})$, the results showed that the activity was quite similar compared to positive control with values of $61.202 \%, 61.202 \%$, $57.452 \%, 57.452 \%$, and $62.924 \%$, respectively, as shown in Fig. 3c. Their activity was also almost the same in different concentrations $(0.78,1.56,3.125,6.25,12.5,25,50,100 \mu \mathrm{g} / \mathrm{ml})$. All samples reduced NO production on RAW264.7 cell line. This study suggested that methanol extracts and fractions of sponge (H. amboinensis) - associated bacteria have potential as anti-inflammatory agents. Thus, methanol extract HM 1.2 and its fractions (fr1, fr2, F1C1, F1C2, F1C3, and F1C4) were selected for further assay to analyze their role as anti-inflammatory agents in inhibiting COX-1, COX-1, and sPLA2 enzyme activity.

\section{Phytochemical screening}

Phytochemical studies were carried out on selected methanol extract (HM 1.2) from H. amboinensis-associated bacteria since this extract revealed high anti-inflammatory activity and it was extracted from the bacteria which grew easily compared to the other active methanol extracts. The results showed that alkaloids and terpenoids were two chemical constituents present in this extract (Table 2). From results

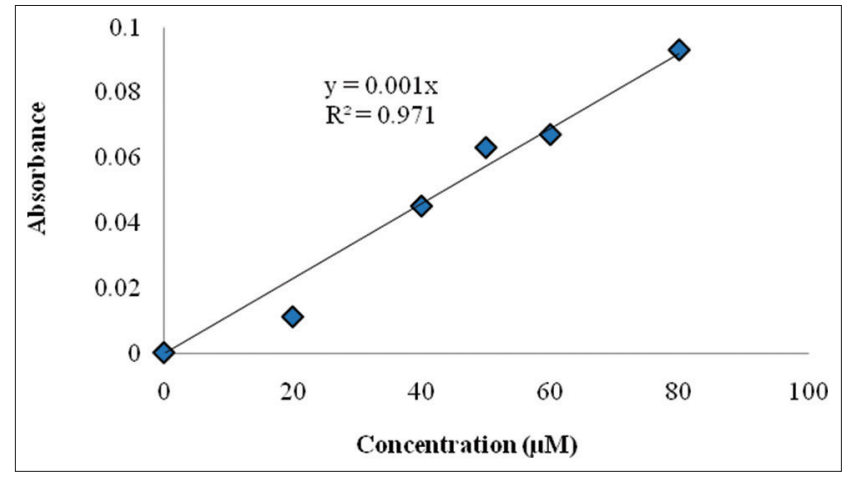

Fig. 2: Nitric oxide standard curve

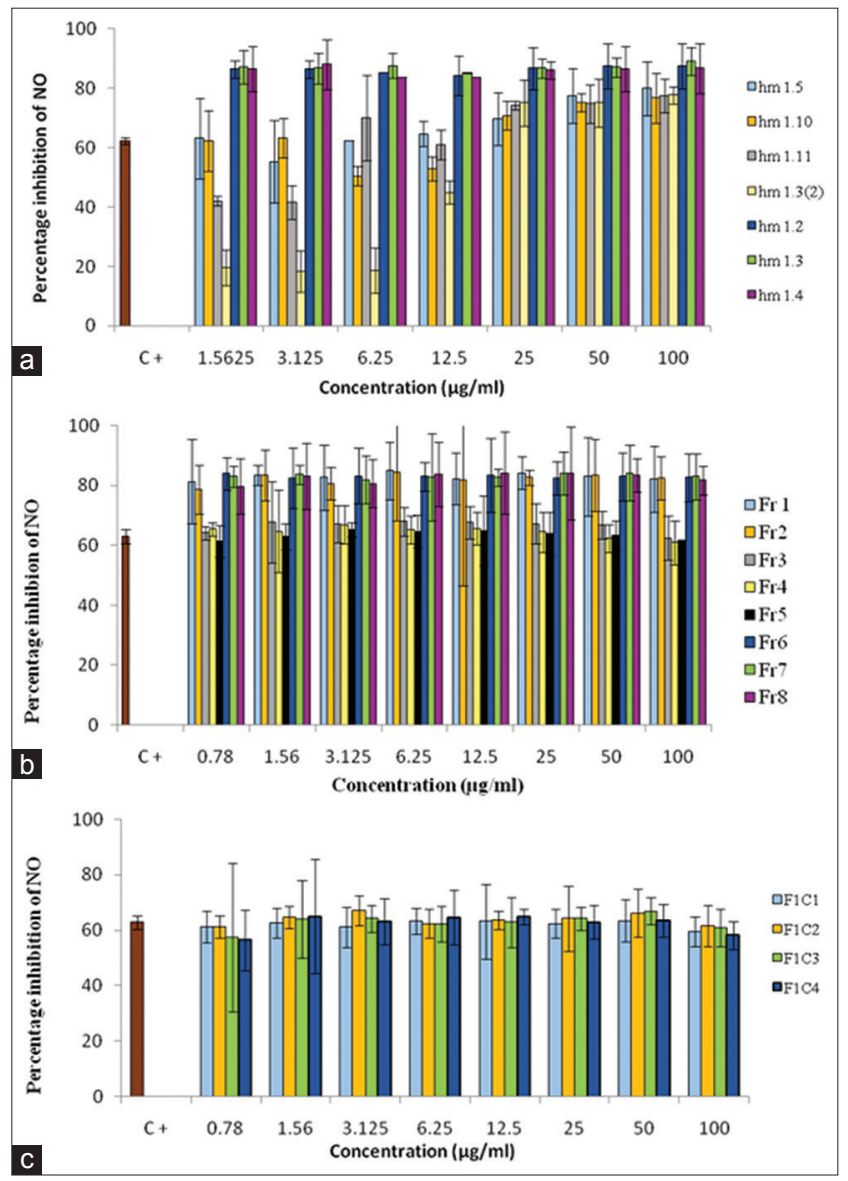

Fig. 3: Inhibitory activity of NO production with LPS stimulated on RAW264.7 by all methanol extracts (a) and HM 1.2 fractions (b and c) of bacteria associated with Haliclona amboinensis)

above, all samples reduced NO production on RAW264.7 cell line. Alkaloids and terpenoids on the methanol extract HM 1.2 could have responsible on reducing NO production. This study suggested that methanol extracts and fractions of sponge (H. amboinensis) - associated bacteria have potential as anti-inflammatory agents. Then, $\mathrm{Hm} \mathrm{1.2,}$ fr1, fr2, F1C1, F1C2, F1C3, and F1C4 were selected for further assay to analyze their role as anti-inflammatory agents in inhibiting COX-1, COX-2, and sPLA2 enzyme activity.

Alkaloids and terpenoids are produced by many organisms, such as bacteria, fungi, plants, and animals. These compound groups have a wide range of therapeutic properties, including antimicrobial, antioxidant, antihypertensive, anticoagulant, anticancer, anti-inflammatory, wound healing and immune modulator, and other medicinal properties [20]. 
Phytochemical properties of the samples had a correlation with their therapeutic properties. Some studies have reported that alkaloid and terpenoids compounds have many potentials as antibacterial [2,3], anticancer and antitumor [4], antidiabetic and antioxidant [5], and anti-inflammatory [6,7] agents. Moreover, alkaloids from marine invertebrates such as sponges are reported to be anti-inflammatory potentials [21].

Effect of methanol extract and fractions in inhibiting COX-1 activity The highest inhibition on COX-1 was shown at the concentration of $2.5 \mu \mathrm{g} / \mathrm{ml}$ by fr1 $(116.886 \pm 4.698 \%)$, followed by extract

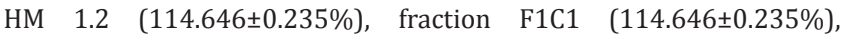
fr2 $(77.001 \pm 3.759 \%)$, fraction F1C3 $(76.299 \pm 3.033 \%)$, fraction F1C2 $(66.405 \pm 0.136 \%)$ and fraction F1C4 $(60.516 \pm 0.282 \%)$. At the concentration of $5 \mu \mathrm{g} / \mathrm{ml}$, positive results were only shown by fr1 $(73.986 \pm 0.194 \%)$. The results in Table 3 revealed that all samples possessed anti-inflammatory activity by inhibiting COX-1 enzyme activity. High activity on all samples could be attributed the group of alkaloids and terpenoids compounds on the methanol extract (Table 1) were present. Synergistic effect between chemical constituents in fraction 1 compared to its fractions (F1C1-F1C4) could have had an effect on its activity, thus fraction 1 possessed anti-inflammatory activity through inhibiting the COX-1 enzyme activity higher than its fractions.

Effect of methanol extract and fractions on inhibiting COX-2 activity Table 4 shows the effect of the methanol extract and its fractions on inhibiting COX-2 enzyme activity.

At the concentration of $2.5 \mu \mathrm{g} / \mathrm{ml}$, the highest activity was yielded by fraction F1C4 with the percentage of inhibition of $116.457 \pm 3.289 \%$, followed by fraction F1C2 (107.362 $\pm 0.235 \%)$, fraction F1C3 (50.495 $\pm 0.658 \%)$, and fraction F1C1 (20.554 $\pm 0.182 \%)$. At the concentration of $5 \mu \mathrm{g} / \mathrm{ml}$, higher inhibition was yielded by fraction 2, while the other samples showed low inhibition activity compared to standard Arginine with the percentage of inhibition ranging from $6.104 \pm 1.856 \%$ to $23.001 \pm 0.507 \%$. According to Milugo et al. [22], antagonistic relationship among phytochemicals would affect the efficacy of crude extracts. In our present study, antagonistic relationship between chemical constituents in extract HM 1.2 and its first fraction (fr1) could have had an effect on inhibiting COX-2 enzyme activity, thus higher inhibition of its second fraction (F1C2 and F1C4) was obtained. Alkaloids and terpenoids compounds in the samples could have also contributed to their activity since these compound groups were detected in the phytochemical study (Table 2).

Effect of methanol extract and fractions in inhibiting sPLA2 activity The effect of the active methanol extract and fractions on inhibiting sPLA2 enzyme activity is shown in Table 5. All samples inhibited sPLA2 enzyme activity, with the highest inhibition obtained by fraction F1C2 $(114.8148 \pm 0.940 \%)$, followed by fraction F1C4 (105.5556 $\pm 0.282 \%)$, fraction Fr2 (88.8889 $\pm 0.507 \%)$, fr1 $(85.1852 \pm 0.235 \%)$, fraction F1C3 $(81.4815 \pm 0.003 \%)$ and extract HM $1.2(70.2667 \pm 1.175 \%)$.

Alkaloids and terpenoids could be responsible for giving antiinflammatory activity through inhibiting sPLA2 enzyme activity pathway. Yedgar et al. [23] suggested that the inhibition of PLA2 isoforms (such as sPLA2 and cPLA2) became a mean to block the synthesis of inflammation mediators resulting from AA metabolism, thus reduce the inflammation. However, there have been no studies reporting their anti-inflammatory potential activity as well as their mechanisms action in inhibiting COX-1, COX-2 and sPLA2 activity.

Some studies on antibacterial and anticancer activity of bacteria associated with sponge have been reported. Tropodithietic acid compound produced by Pseudovibrio sp. correlated sponge-associated bacteria was identified to be responsible for the antibacterial activity. These bacteria also produced phenolics chemical constituents [24].
Table 2: Phytochemical screening on active methanol extract HM 1.2 of bacteria associated with $H$. amboinensis

\begin{tabular}{ll}
\hline Phytochemical test & Phytochemical result \\
\hline proteins and amino & - \\
acids & - \\
Carbohydrates & - \\
Flavonoids & - \\
Phenols & - \\
Steroids & - \\
Glycosides & + \\
Terpenoids & + \\
Alkaloids & + \\
\hline+ Phytochemical presence in the sample, H. amboinensis: Haliclona amboinensis
\end{tabular}

Table 3: Percentage of inhibition on COX-1 enzyme activity

\begin{tabular}{lll}
\hline Sample & \multicolumn{2}{l}{ Percentage of inhibition } \\
\cline { 2 - 3 } & $\mathbf{C O X}-\mathbf{1}(\mathbf{5} \boldsymbol{\mu g} / \mathbf{m l})$ & $\mathbf{C O X}-\mathbf{1}(\mathbf{2 . 5} \boldsymbol{\mu g} / \mathbf{m l})$ \\
\hline HM 1.2 & ND & $114.646 \pm 0.235$ \\
fr1 & $73.986 \pm 0.194$ & $116.886 \pm 4.698$ \\
fr2 & ND & $77.001 \pm 3.759$ \\
F1C1 & ND & $77.497 \pm 2.936$ \\
F1C2 & ND & $66.405 \pm 0.136$ \\
F1C3 & ND & $76.299 \pm 3.033$ \\
F1C4 & ND & $60.516 \pm 0.282$ \\
Arginine & 100 \pm 0.000 & $100 \pm 0.000$ \\
\hline
\end{tabular}

Result were expressed as the means \pm SD of three independent experiments ( $\mathrm{n}=3)$, SD: Standard deviation

Table 4: Percentage of inhibition on COX-2 enzyme activity

\begin{tabular}{lll}
\hline Sample & \multicolumn{2}{l}{ Percentage of inhibition } \\
\cline { 2 - 3 } & $\mathbf{C O X}-\mathbf{2}(\mathbf{5} \boldsymbol{\mu g} / \mathbf{m l})$ & $\mathbf{C O X}-\mathbf{2}(\mathbf{2 . 5} \boldsymbol{\mu g} / \mathbf{m l})$ \\
\hline HM 1.2 & $20.511 \pm 0.940$ & $\mathrm{ND}$ \\
fr1 & $23.001 \pm 0.507$ & $\mathrm{ND}$ \\
fr2 & $46.927 \pm 2.805$ & $\mathrm{ND}$ \\
F1C1 & $21.344 \pm 1.391$ & $20.554 \pm 0.182$ \\
F1C2 & $6.945 \pm 3.524$ & $107.362 \pm 0.235$ \\
F1C3 & $0.874 \pm 2.349$ & $50.495 \pm 0.658$ \\
F1C4 & $6.104 \pm 1.856$ & $116.457 \pm 3.289$ \\
Arginine & $100 \pm 0.000$ & $100 \pm 0.000$ \\
\hline
\end{tabular}

Result were expressed as the means \pm SD of three independent experiments $(n=3)$. ND: Not detected, SD: Standard deviation

Table 5: Percentage of inhibition on SPLA2 enzyme activity

\begin{tabular}{ll}
\hline Sample $(\mathbf{1} \boldsymbol{\mu g} / \mathbf{m l})$ & Percentage of inhibition \\
\hline HM 1.2 & $70.2667 \pm 1.175$ \\
fr1 & $85.1852 \pm 0.235$ \\
fr2 & $88.8889 \pm 0.658$ \\
F1C1 & $88.8889 \pm 0.507$ \\
F1C2 & $114.8148 \pm 0.940$ \\
F1C3 & $81.4815 \pm 0.003$ \\
F1C4 & $105.5556 \pm 0.282$ \\
Arginine & $100 \pm 0.000$ \\
\hline Result were expressed as the means \pm SD of three independent
\end{tabular}

experiments $(n=3)$, SD: Standard deviation

Moreover, melanin from Marin Bacillus spp. BTCZ31 showed antiinflammatory activity via inhibited the activity of COX and LOX enzyme [25]. Some new aminophenoxazinones alkaloids isolated from a marine bacteria, Halomonas sp. have shown antibacterial and cytotoxic activities against some tumor cell lines, HM02 (gastric adecocarcinoma), HepG2 (hepatocellular carcinoma) and MCF-7 (breat adecocarcinoma) [26]. Moreover, some new terpenoids, namely aspergiterpenoid A, (-)-sydonol, and (-)-sydonic acid have been isolated 
from bacteria Aspergillus sp. associated with marine sponge Xestospongia testudinaria. These terpenoids showed very good antimicrobial activity against Escherichia coli and Micrococcus tetragenus [27].

Secondary metabolites from bacteria associated with $H$. amboinensis which contained alkaloids and terpenoids could possess antiinflammatory activity via some roles. Inhibition of NO synthesis by inhibitors (alkaloids and terpenoids from bacteria associated with H. amboinensis will be inhibited of PGs production. According to Issa et al. [28], inhibiting PGs consequently will decrease all proinflammatory mediators such as PGE2 and NO, thus the inflammation will be reduced. In addition, releasing of PGs by inhibiting COX-1 and COX-2 enzymes activity through inhibiting sPLA2 activity could have also contributed on reducing the inflammation. Yedgar et al. [23] have reported that the inhibition of PLA2 isoforms (such as SPLA2 and cPLA2) as a mean to block the synthesis of inflammation mediators resulting from AA metabolism.

\section{CONCLUSIONS}

This study revealed that bacteria associated with $H$. amboinensis could have anti-inflammatory potential via reducing NO production and inhibiting COX-1, COX-2, and sPLA2 enzymes activity. Further study to identify the name of bacteria isolates from $H$. amboinensis-associated bacteria which produced anti-inflammatory agents and isolate the bioactive compounds are needed to support their activity.

\section{ACKNOWLEDGMENTS}

The authors wish to thank the Ministry of Higher Education for the fund provided under the RAGS Fasa II/2013 (Vote No.57103). Appreciation goes to Institute Marine Biotechnology, UMT, Kuala Nerus, Malaysia, for running all assays.

\section{REFERENCES}

1. Lubberts E, Van den Berg WB. Cytokines in the Pathogenesis of Rheumatoid Arthritis and Collagen-Induced Arthritis. Madame Curie Bioscience Database. Austin, TX: Landes Bioscience; 2000. p. 2000-13.

2. Cushnie TP, Cushnie B, Lamb AJ. Alkaloids: An overview of their antibacterial, antibiotic-enhancing and anti-virulence activities. Int $\mathrm{J}$ Antimicrob Agents 2014;44(5):377-86

3. Mabhiza D, Chitemerere T, Mukanganyama S. Antibacterial properties of alkaloid extracts from Callistemon citrinus and Vernonia adoensis against Staphylococcus aureus and Pseudomonas aeruginosa. Int J Med Chem 2016;2016:6304163.

4. Li X, Li JR, Chen K, Zhu HL. A functional scaffold in marine alkaloid: An anticancer moiety for human. Curr Med Chem 2013;20(31):3903-22.

5. Tiong SH, Looi CY, Hazni $\mathrm{H}$, Arya A, Paydar M, Wong WF, et al. Antidiabetic and antioxidant properties of alkaloids from Catharanthus roseus (L.) G. Don. Molecules 2013;18(8):9770-84

6. Souto AL, Tavares JF, da Silva MS, Diniz Mde F, de Athayde-Filho PF, Barbosa Filho JM. Anti-inflammatory activity of alkaloids: An update from 2000 to 2010. Molecules 2011;16(10):8515-34

7. Prakash V. Terpenoids as source of anti-inflammatory compounds. Asian J Pharm Clin Res 2017;10(3):68-76.

8. Boobathy S, Soundarapandian P, Subasri V, Vembu N, Gunasundari V. Bioactivities of protein isolated from marine sponge, Sigmadocia fibulatus. Curr Res J Biol Sci 2009;1(3):160-2.

9. Yadav RN, Agarwala M. Phytochemical analysis of some medicinal plants. J Phytol 2011;3(12):10-4.

10. Jaganathan SK, Mandal M. Antiproliferative effects of honey and of its polyphenols: A review. J Biomed Biotechnol 2009;2009:830616.
11. Andriani Y, Ramli NM, Syamsumir DF, Kassim MN, Jaafar J, Azis NA, et al. Phytochemical analysis, antioxidant, antibacterial and cytotoxicity activities of keys and cores part of Pandanus tectorius fruits. Arab J Chem. DOI: 10.1016/j.arabjc.2015.11.003

12. Kassim M, Achoui M, Mustafa MR, Mohd MA, Yusoff KM. Ellagic acid, phenolic acids, and flavonoids in Malaysian honey extracts demonstrate in vitro anti-inflammatory activity. Nutr Res 2010;30(9):650-9.

13. Yi PF, Bi WY, Shen HQ, Wei Q, Zhang LY, Dong HB, et al. Inhibitory effects of sulfated 20(S)-ginsenoside Rh2 on the release of proinflammatory mediators in LPS-induced RAW 264.7 cells. Eur J Pharmacol 2013;712(1-3):60-6.

14. Lau KM, Lai KK, Liu CL, Tam JC, To MH, Kwok HF, et al. Synergistic interaction between astragali radix and rehmanniae radix in a Chinese herbal formula to promote diabetic wound healing. J Ethnopharmacol 2012;141(1):250-6.

15. George A, Chinnappan S, Chintamaneni M, Kotak CV, Choudhary Y, Kueper T, et al. Anti-inflammatory effects of Polygonum minus (Huds) extract (Lineminus ${ }^{\mathrm{TM}}$ ) in in-vitro enzyme assays and carrageenan induced paw edema. BMC Complement Altern Med 2014;14:355.

16. Andriani Y, Effendy AW, Habsah M, Sifzizul TM. Antibacterial, radical scavenging activities and cytotoxicity properties of Phaleria macrocarpa (Scheff.) Boerl. Leaves in HepG2 cell lines. Int J Pharm Sci Res 2011;2(7):1700-6

17. Hammond RA, Hannon R, Frean SP, Armstrong SJ, Flower RJ, Bryant CE. Endotoxin induction of nitric oxide synthase and cyclooxygenase- 2 in equine alveolar macrophages. Am J Vet Res 1999;60(4):426-31.

18. Radzi SA, Andriani Y, Mohamad H, Muhammad TS, Saidin J. In vitro anti -inflammatory activities of extracts from bacteria associated with marine sponges: Theonella sp. J Teknol 2015;77(25):165-9.

19. Yoon WJ, Ham YM, Kim SS, Yoo BS, Moon JY, Baik JS, et al. Suppression of pro-inflammatory cytokines, iNOS, and COX-2 expression by brown algae Sargassum micracanthum in RAW 264.7 macrophages. EurAsian J Biol Sci 2009;3:130-43.

20. Perdicaris S, Vlachogianni T, Valavanidis A. Bioactive natural substances from marine sponges: New developments and prospects for future pharmaceuticals. Nat Prod Chem Res 2013;1(3):1-8.

21. Senthilkumar K, Kim SK. Marine invertebrate natural products for antiinflammatory and chronic diseases. Evid Based Complement Alternat Med 2013;2013:572859.

22. Milugo TK, Omosa LK, Ochanda JO, Owuor BO, Wamunyokoli FA, Oyugi JO, et al. Antagonistic effect of alkaloids and saponins on bioactivity in the quinine tree (Rauvolfia caffra sond.): Further evidence to support biotechnology in traditional medicinal plants. BMC Complement Altern Med 2013;13:285.

23. Yedgar S, Lichtenberg D, Schnitzer E. Inhibition of phospholipase A(2) as a therapeutic target. Biochim Biophys Acta 2000;1488(1-2):182-7.

24. Penesyan A, Tebben J, Lee M, Thomas T, Kjelleberg S, Harder T, et al. Identification of the antibacterial compound produced by the marine epiphytic bacterium Pseudovibrio sp. D323 and related spongeassociated bacteria. Mar Drugs 2011;9(8):1391-402.

25. Kurian NK, Nair HP, Bhat SG. Evaluation of anti-inflammatory property of melanin from marine Bacillus spp. BTCZ31. Asian J Pharm Clin Res 2015;8(3):251-5.

26. Bitzer J, Grosse T, Wang L, Lang S, Beil W, Zeeck A. New aminophenoxazinones from a marine Halomonas sp.: Fermentation, structure elucidation, and biological activity. J Antibiot (Tokyo) 2006;59(2):86-92.

27. Li D, Xu Y, Shao CL, Yang RY, Zheng CJ, Chen YY, et al. Antibacterial bisabolane-type sesquiterpenoids from the sponge-derived fungus Aspergillus sp. Mar Drugs 2012;10(1):234-41.

28. Issa AY, Suresh VR, Wargovich MJ. The role of phytochemicals in inhibition of cancer and inflammation. New directions and perspectives. J Food Compost Anal 2006;19:405-19. 